\title{
Contributions to Meaning from First Year Nursing Degree Students
}

\author{
Laura Martínez Rodríguez¹, Oscar Bautista Villaécija, \\ Esther Insa Calderón ${ }^{2}$ \\ ${ }^{1}$ Department of Nursing Foundation, Sant Joan de Déu Campus Docent, Barcelona, Spain \\ ${ }^{2}$ Departament of Innovation, Sant Joan de Déu Campus Docent, Barcelona, Spain \\ Email:lmartinez@santjoandedeu.edu.es
}

How to cite this paper: Rodríguez, L. M., Villaécija, O. B., \& Calderón, E. I. (2018). Contributions to Meaning from First Year Nursing Degree Students. Creative Education, 9, 1342-1358.

https://doi.org/10.4236/ce.2018.99100

Received: April 10, 2018

Accepted: July 20, 2018

Published: July 23, 2018

Copyright $\odot 2018$ by authors and Scientific Research Publishing Inc. This work is licensed under the Creative Commons Attribution International License (CC BY 4.0).

http://creativecommons.org/licenses/by/4.0/

\begin{abstract}
Purpose: To comprehend the meaning and perception of the meaning of life as expressed by first-year nursing students. From this meaning, we sought to identify concepts and elements linked to nursing care and to extract useful generalizations so as to better understand this practice and contribute to the development of the discipline. Design: This study is based on grounded theory qualitative research undertaken with first-year nursing students. Method: This is a qualitative study in the social constructivist paradigm, following an interpretive grounded theory methodology. Sample was recruited by mutual agreement. Reliability and ethical criteria were applied. Findings: From the analysis of the contributions made to the students' forum, five categories emerged: 1) attitude in the face of suffering, 2) freedom and love, 3) empathy in the face of extreme suffering, 4) meaning of suffering, 5) meaning of life and freedom. Conclusions and implications: The reflections of future healthcare professionals represent a contribution to comprehending meaning in human life. In order to confront the search for meaning in situations marked by suffering, the individual may manifest various attitudes that are seen primarily as defense mechanisms, but in which inhere values such as hope and resilience. Clinical Relevance: The three paths proposed by Víctor Frankl are use to nurses in finding meaning in their profession: feeling useful in providing personal care, loving another human and finding the value in life, in particular when suffering is unavoidable. This knowledge is critical for educators seeking to promote genuinely care.
\end{abstract}

\section{Keywords}

Meaning of Life, Nursing, Suffering, Empathy 


\section{Introduction}

The search for basic meaning in life has been continuous throughout human history, and today it is closely linked to the general concept of health (Schwartzmann, 2003; Delgado, 2007; Angermeyer \& Killian, 2000), especially regarding those suffering cancer (Vinaccia \& Quiceno,2012), in an end-of-life situation (Pessini \& Bertachini, 2006), and with problems of mental health (Viera, López, \& Barrenechea, 2006).

Finding meaning in life enhances subjective psychological well-being (Acklin, Brown, \& Mauger, 1988; Zika \& Chamberlain, 1992), increases sociability (Pearson \& Sheffield, 1974), reduces psychopathological alterations (Yalom, 1984), and lessens the impact of stressful and conflictive situations (Vickberg et al., 2000). From this perspective, nurses have shown their concern with the search for meaning through their holistic, integrative approach to the care they provide (Shiratori, Figueiredo, \& Teixeira, 2006; Lima \& Rosa, 2008; Peña \& Carlos, 2012).

Uncovering meaning in life and exploring the elements that make it up in order to be able to provide holistic care entails the acquiring of concrete patterns of knowledge-scientific (cognitive learning) and practical (practical/empirical learning), an ethical identity (ethical behavior), and learning about oneself (self-knowledge), which together guide the professional in the acquisition of experience and competence during study towards a nursing degree (Carper, 1978).

The modern world is not only characterized by an increase in technology that allows for intervention in cases that in other times might have lacked hope for survival. To this technological advance, we must also add social and cultural attitudes that place an emphasis on the individual as the protagonist in life. $\mathrm{Hu}$ man beings live and act driven by their interest in satisfying their needs, from the simplest and most basic to guarantee their continued existence, to the most complex and spiritually imbued. But in the drive to satisfy their needs and with the goal of organizing their lives to do so, humans also create problems by virtue of their interaction with others in society. From this situation, there emerge questions about how to live, the meaning of life, and even whether or not it is worth living (Cabrera, Luch, \& Casas, 2008).

This is the case of spiritual care, which includes the question of meaning and which is a part of the total care offered by nursing professionals. The holistic concept of care encompasses all the dimensions of the human being, including the spiritual dimension (McSherry \& Cash, 2004).

Given the foregoing, today there is heightened concern and interest among nursing school faculty to include new elements in their curricula that attend not only to technological competence, but also to the ontological as well. This expanded scope is essential to the evolving maturity, and indeed the survival, of the nursing profession as a discipline (Watson, 2002; Gray, 2009).

In order to grapple with the spiritual dimension of nursing, we need to under- 
stand how the spirituality of the human being is involved in the two key players in care: the person being cared for and the person providing the care.

There have been several quantitative studies that have attempted to measure, by means of scales, the meaning of life for university students in order to link it, positively or negatively, with the existential vacuum, desperation, and suicide (Jaramillo, Carvajal, Marín, \& Ramírez, 2008; García-Alandete, Gallego-Pérez, \& Pérez-Delgado, 2009; Cassaretto \& Martínez, 2012). There have been qualitative studies as well of the experience of nursing students participating in providing palliative care (Hold, Blake, \& Ward, 2015). In spite of the significance of the meaning of life in the global picture of health in human beings, there is a dearth of qualitative published studies engaging the question among nursing professionals and students (Lima \& Rosa, 2008). Reflection upon this question among those training to become future providers of care is of great importance, given that it is in their stage of life, early adulthood, that the progressive acquiring of personal autonomy and the establishment of individual life goals take place (Rice, 1997). This is also the stage of adult life in which suicidal ideation most often occurs (Koven, 2001).

It was through our reading of Man's Search for Meaning by Viktor Frankl that we undertook an exploration of the meaning of the "meaning of life" for first year students at the Sant Joan de Déu Nursing School, in the course entitled Historical, theoretical, and methodological foundations of nursing. We began reflecting individually, and then collectively, on the elements that are of importance in extreme situations such as serious illness, suffering, and death, as they are treated in the experiences related in the book.

Total care for the individual begins with recognition of the other person as a unique being, with particularities and characteristics that are exclusively his or hers-a being both free and possessed with dignity (Laverde, 1998). This "other" carries his or her own life experience, reflected in customs, beliefs, values, and attitudes constructed upon the foundation of a personal history.

The nurse aspires to find in both the "other" and himself or herself the experiences, feelings, and emotions that are unique to the individual in order to begin to comprehend what happens to the meaning of life when the phenomenon of illness intrudes.

The relationship of providing care is a relationship of encounter, of a confluence of meanings given shape by the existential experience of the human being. There is a convergence as well of meaning, the sense of caring, and the sense of being cared for by another. And the "meaning" of being cared for is closely tied to the "meaning" of the illness, and consequently of the suffering which obliges the patient to submit to activity upon his or her person at a time of great vulnerability which also exposes the patient to the needs of the other vis a vis himself or herself.

The objective of this study was to comprehend the meaning and perceptions of the meaning of life as expressed by first-year nursing students. From this meaning we then sought to identify concepts and elements linked to nursing 
care and to extract useful generalizations so as to better understand this practice and contribute to the development of the discipline.

We also undertook to describe the areas and topics that future nursing professionals considered important in the approach to total care for the patient and in relation to the meaning of life of these people.

\section{Theoretical Framework}

In the modern world the term "crisis" is no longer used for a passing accident but rather for a structural phenomenon. Anxiety, stress, and fear are becoming inherent elements of human existence (Frankl, 2000). Modern pluralism, which allows for coexistence and competition among different systems of values, permits individuals to delegate reflection about meaning to various kinds of institutions, thereby being relieved of the heavy burden of having to reinvent the world for themselves each day (Berger \& Luckmann, 1968).

Beginning with the idea that our reality has some meaning, or at least attributing some meaning to it, we understand by "meaning" the search for intelligibility or the will to give meaning to reality, history, and the intrinsic logic of everything that takes place. We search for that which underlies and explains what we experience, both from a general point of view and for each of the situations that we may find ourselves in, both individually and collectively.

Meaning may be understood, then, as a perception that provides signification and that emerges from the internal experience in contact with the outside reality (Längle, 2005), generating cognitive structures that provide signification to different situations every day (Antonovsky, 1987), and thereby provide existential coherence. For Frankl (1946) there would be something more than the perception of the environment as a significant totality, given that humans seek to find an interpretation that will reveal to them as individuals an important objective that they must fulfill, influenced by cultural factors, past experiences, level of knowledge, and the belief system that each human holds (Lipowski, 1970).

The search for meaning involves two components: the search for order (situating an event in a wider context, such as a life scheme) and an objective (perception of a mission or goal).

We find today the paradoxical situation that this search for meaning assumes that the world is predictable and controllable, and that the logic that governs its functioning, which we trust, is both good and just (Janoff-Bulman, 1992), yet one of the most generalized of phenomena in today's world concerns the loss of elements that are indispensable such as the ability to choose and to participate in the realization of oneself in contact with social and natural otherness.

What is important is not the meaning that is found, but rather that it turns out to be satisfactory in life in general or in a specific situation (Davis, Nolen-Hoeksema, \& Larson, 1998).

The human being does not construct the significance of his or her being in terms of convenience, but rather thanks to uncovering what meaning is in terms 
of the different situations in life, and through understanding oneself in order to learn what one's attitude should be in the face of life in general and in specific situations (Frankl, 1988; Längle, 2005).

Meaning is what makes life worth living. This is not something that in and of itself is waiting to be grasped, but rather is something intrinsic in each human being, expressed through the spiritual dimension that experiences circumstances, questions them, and confronts them in order to find reasons to keep going on (Frankl, 2000).

Situations like illness, aging, and suffering position the individual to be able to comprehend (Frankl, 1988; Davis, Nolen-Hoeksema, \& Larson, 1998) and to assimilate unforeseen and seemingly difficult experiences (Bonilla \& Rapso, 1997).

Personal meaning could be defined as a complex achievement of the human spirit that arises from the individual confrontation (a constant) with the challenges thrown up by the world and oneself, and which allows individuals to develop their potential (Längle, 2005). It is related to four basic conditions which in turn make up an existential reason: first, investigation actively taken up by oneself, accepting the positive aspects of reality and tolerating those that cannot be changed; second, the search for a positive relation with reality in order to value it, and use it as a basis for building worthy interpersonal relations, finding time for relaxation, and becoming closer to things; third, there is finding oneself in a satisfactory manner and having a real identity, and through attention, the search for justice, and self-esteem, the possibility of self-discovery through interpersonal encounters with others; and finally, having a goal in life, which requires a domain of activity and a context upon which a structure may be erected for doing things of value in the future.

The search for meaning is a call for the healthcare professional to confront the existential vacuum of the other, who is ill and vulnerable, and to comprehend this dimension and work to establish a relationship of help, reflecting upon existential motivation and focusing on the patient at all possible levels (Kérouac et al., 2001).

Self-reflection develops the human capacity to emerge from oneself and observe, confront oneself, and even laugh at oneself. The reflective side of a human being can view himself or herself as another. To create distance from oneself is to see oneself from the outside-to spy on oneself, as it were. This is how the individual can achieve a self-transformation, deciding how to think and act, while always conscious of being a part of a specific context.

\section{Methodology}

\subsection{Scope}

The scope of the study is Sant Joan de Déu Nursing School, within a Public University of Barcelona. It Schools belong to the Catholic Order of Saint John of God, which has as a care framework the values of hospitality, respect, responsibility, quality, and spirituality. 


\subsection{Design}

This is a qualitative study, in that we are attempting to understand the meanings through the discussions and reflections of a group of first year nursing students.

The paradigmatic perspective is in the framework of social constructivism, focused on the collective generation of meaning, in this case specifically via language and the social interaction in the class group (Berger \& Luckmann, 1968).

The method of investigation used is the grounded theory design. We considered this methodology to be the most appropriate to help bring us closer to subjective processes that are lacking in antecedents, as it allowed us to use the frames of reference of those actually involved (Strauss \& Corbin, 1997; Glaser \& Strauss, 2017).

\subsection{Participants}

The study sample was recruited by mutual agreement (Hernández-Sampieri, Fernández-Collado, \& Baptista-Lucio, 1998). The participants were 153 first-year students in the university degree program. Of these 153 students, $10.3 \%$ were male and $89.7 \%$ female. Of the total, $96.7 \%$ were between 18 and 30 years of age, and $3.3 \%$ were over 30 .

1) Inclusion criteria:

First-year student

Read the book Man's Search for Meaning

2) Exclusion criteria: not fulfilling the inclusion criteria.

3) Method of recruitment

The following strategies were followed: The study sample was recruited by mutual agreement (Hernández-Sampieri, Fernández-Collado, \& Baptista-Lucio, 1998) in nursing class.

\subsection{Data Collection Methods}

1) Instruments

The data collection techniques used were open written questions (Q) and discussion group (DG).

Following the reading of the book Man's Search for Meaning by the students, an answered questions analysis of their individual contributions using digital support, they explained which aspects of the book had most caught their attention, which they had liked most, or simply which they thought most worthy of keeping in mind, and what ideas emerged on it.

After the questionnaire analysis, we made discussions groups. The method of discussion group is considered a specific technique within the wider category of group interviews. The method was chosen because with the subject at hand, a study of meanings, the interaction of participants increases the level of discussion concerning daily situations which in turn helps in the identification of which concepts are fundamentals in the discussion. The composition of each group was homogeneous. Each group was made up of from 12 - 15 participants, 
as well as two researchers from the team [one leading the group dynamics and the other acting as observer]. The group discussions and the in-depth interviews were recorded.

\subsection{Analysis Strategies}

All of the generated data were transcribed. Analysis was carried out following the process of Grounded Theory. This process of analysis was chosen because there were not preliminary ideas about the topic. An exhaustive analysis and constant comparison of behavior and attitudes, in terms of properties and dimensions, was carried out in order to be able to interpret the data of this investigation. Interaction between the inter-disciplinary researchers (nurse-phylosopher-phycologist) and the data was sought out. Microanalysis was made with the primary data; this was an important process in the construction of theory (Barbera, Garcia, \& Fuertes-Alpiste, 2017).

In order to assure maximal rigor, the process of analysis of the data from each DG was triangulated simultaneously by tree researchers and the partial results generated were analyzed jointly, first by pairs and then by the entire team, until consensus was reached concerning the main typologies. Later, the final report was prepared by the two principal investigators of the project. Throughout the process the research team held meetings regularly to make decisions about the development of the DGs and Qs, and to resolve organizational questions that arose. Data saturation was achieved.

\subsection{Criteria for Rigor Implemented}

Reliability criteria were implemented (Guba \& Lincoln, 1989).

1) Credibility criteria. The transcriptions of the group discussions and interviews were returned to the participants for validation and/or modification of data. The principle of saturation of data was applied to extend the DGs and Qs in depth. On the basis of this criterion one DG, that of users, was extended given the wealth of information yielded by the first group. Triangulation was also carried out in the generating of data, for DGs, Qs, and documentary sources, such as analysis by pairs. The make-up of the DGs was heterogeneous between them and homogeneous with respect to each group. The researchers who led the group discussions did not participate in the first analysis of them.

2) Transferability criteria. The results of the present study have been exhaustively described and may be of use to other students with similar characteristics, as well as healthcare workers.

3) Dependence. The decisions made during the research process have been described. The participants fulfilled the inclusion criteria that were laid out.

4) Conformability criteria. The positioning of the research team was described in the introduction to the study.

\subsection{Ethical Criteria}

The ethical criteria were applied during the entire research process. The study 
was approved by the Research Committee of the University. All participants remained anonymous. The research team was fully committed to maintaining the data and then seeing to its destruction within a period of two years. All participants gave their signed informed consent prior to receiving information about the process.

\section{Results and Discussion}

From the analysis of the contributions made to the students' Moodle forum and the Focus Group five categories emerged: 1) Attitude in the face of suffering, 2) Freedom and love, 3) Empathy in the face of extreme suffering, 4) Meaning of suffering, 5) Meaning of life and freedom.

Results from the discussion groups in the five categories:

\subsection{Attitude in the Face of Suffering}

The first category that emerges is that of the importance of attitude in the face of suffering. From the point of view of students, this phenomenon is seen as one of the most fundamental elements in carrying out activity rather than in maintaining health.

By suffering we understand a psychological reaction brought on by a painful fact (physical or non-physical) of variable duration, that bears a close relation for the subject to the significance of the fact that brings it on. Nevertheless, suffering may appear without there being a painful fact present; the recollection of the fact may be enough to make it reality (Cabrera, Lluch, \& Casas, 2008).

Considering that illness appears as a many-faceted, destabilizing accident (De Llanos, 2001) that generates suffering in human beings, they in turn have a range of individual resources with which to confront it, which they will use because human nature is driven by and towards survival. Suffering is part of life; its solution depends upon our creating the appropriate response to the painful reality, so as it overcome it (Cabrera, Lluch, \& Casas, 2008).

The first-year nursing students identified a series of mechanisms available to confront suffering: Imagination to generate a reality different, sense of humor, memories (happy circumstances) generosity, reducing sensitivity, adaptation, loneliness and regression:

Freedom of thought may be a central focus in survival; in thinking you imagine, create, and look forward to things. Thought affords the human being the privilege to avoid reality by becoming stronger, growing, and continuing to have a vision of the future (E004).

When a person suffers for some reason, there needs to be a way to compose himself or herself in order to escape, as in this case by using the imagination as a kind of palliative for the suffering (E138).

Dreams are a useful resource for getting away from pain for a spell(E143).

...it makes me think positively, optimistically, which then makes it possible to face life more easily when the unexpected occurs [...] a sense of humor makes 
you search for meaning in order to soldier on against the suffering, and thereby survive.

I've come to understand that there comes a point when, in order to survive the harsh reality here, you have to get away from it. If not, survival is impossible. So the only thing you have left is your past [...] you realize that thanks to love you can survive: "Salvation is only possible in love and through love." You grasp love to move ahead, even though that past person is no longer alive. What matters is your memory, your spiritualized figure (E013).

Maybe holding on to memories can create hope, but when that goes everything that you have lived goes. There is no way to hope for anything better, at least for me. Memories can keep you sane at times. When you lose them, or they are wiped out, you lose your identity (E147).

I hang on to life by helping others, making up for the lack of life or hope by hanging on to the help I give those around me who are going through a bad time.

Your feelings were inhibited because you felt more dead than alive (E069). You get to a point where your emotions begin to disappear, because you are living day after day with such suffering that you tell your brain to deactivate in self-defense so that you can stop feeling, and start surviving (E085).

A mental suffering leaves you without seeing any meaning in life. Your body is like a piece of human meat, since you only have the physical dimension left. The psychological and spiritual dimensions are seriously affected (E091).

It really hits hard. You reach the limit, where the blows don't hurt as much as the mental anguish caused by the injustice and irrationality of it all. I try to imagine that by enduring daily blows, you enter into a state of shock in which you stop feeling pain (E088).

It's frightening how people can get used to pain and terror little by little, and undergo horrible experiences without hardly even taking note of them (E070). Humans can adapt well beyond what you might imagine (E081).

I believe that in times that are so hard people have two options. bear up and not let things inside or outside affect you, or else let yourself be carried away by emotion and lose the ability to control them (E075).

In those really difficult moments you have to stand apart from the rest of the world for a while and get away from your problems, isolating yourself from everything going on around you and calmly give vent to what you feel without anyone there to watch you or judge you (E095). All of this makes you think about the terrible and unfair degradation of the person, to the point where self-esteem is so reduced that the rational limits are passed and the internal desire to just disappear in the multitude takes hold, consciously melting into the mass like a herd of sheep, only knowing, thinking, and wanting something (E116).

The physical wear and tear and the need to concentrate on staying alive forces you to descend to primitive levels of internal life [...] what is usually called " $r e-$ gression" (E129).

They cited as the most significant of these hope (not seen as a defense me- 
chanism or a resource, but rather as a value):

Hope played an important role in people and in their way of looking at life (E089).

It is not an attitude. Either you have it or you don't. It is related to mental strength and resilience. When it is lost people may lose their capacity to keep up the struggle (E046).

Even someone sentenced to death will hold on to a shred of hope for a pardon till the bitter end. We are not made to be able to take in our own death. That's why even in the hardest of conditions you help each other and dream of the day in which you will get out (E117).

Beyond what their professional abilities have to offer, transmitting hope is one of the most important missions for these future healthcare professionals. They see it as a key element in confronting suffering (García-Monge, 2010).

The relationship between hope and well-being, and therefore quality of life, appears to be related to the capacity of the individual to overcome suffering:

When everything has been taken away, even dignity and the desire to live, the brain is still intelligent and tries to reduce our suffering to a minimum. We all have this internal freedom of thought, and the desire to be in a better place. It is often the very motor of our lives (E137).

And he or she generates resilience, as the culmination of the process of overcoming (Fiorentino, 2008; Ramírez-Osorio \& Hernández-Mendoza, 2012):

Owing to all the bad experiences one loses one's feelings, or perhaps gains the ability to control them. This is a good thing, in that we have painful situations every day. So the insensitivity helps you to put up with the bad and keep going [...] never losing hope and keep going ahead until the last moment (E001).

At the moment when you start to think about your existence and death, and not knowing your destiny, you can only think that if you survive the now you will go through phases and continue to see your existence in play. You can only let things run their course (E054).

Thinking about the capacity of the human being to find appropriate mechanisms for enduring total suffering, when in a situation of absolute despair, simply finding strength in the image of a loved one. It is moving how the intensity of past experience can help shut out the horrifying present situation in which one may find oneself $(E 105)$.

There are times when this resistance takes our very existence to the limit, where we experience thoughts and feelings also encountered at the existential limits (Amar, 2001):

Every individual will act differently in the same situation. Each individual is a world, and you decide how to respond to life and to the situations that it throws in your path (E007).

Suicide then appears as a reasonable and legitimate way to end a situation of suffering. Suicide doesn't present itself as a psychopathological phenomenon, but rather as a vital event in response to the inability to tolerate suffering ( $\mathrm{Ca}$ sullo, 2005): 
...but being on the receiving end of mistreatment, both physical and psychological, day in and day out without committing suicide means that there is an inexplicable mental strength. Now I understand why some people preferred to die in the gas chambers rather than continue with this torture (E088).

I am surprised by the strength of all those who chose, unfairly, to give up fighting to live, since they were experiencing such suffering and could see no way out (E103).

\subsection{Freedom and Love}

Emerging as important, well-articulated codes were freedom and love:

The importance of being free to be able to decide about anything that affects you. Of note, in life there are many things that can make you opt one way or another (E055).

Our freedom ends where that of another begins, but this is not the case when there is conflict (E096).

There is the possibility of choice, from which there are consequences (E121).

The non-existence of freedom brings the dignity of the person into question. The individual must have the last word (E079).

Not only the love that can arise in a marriage, but also the love of happiness, of God, and of a higher aspiration, or, even a simple, "May you have the choicest morsels of the meal." Love gives meaning to our lives and also helps mark out goals, since it is our greatest aspiration (E071).

The possibility of choice that people have in the face of different situations in life was seen as important by the students, in that freedom is seen to reside the dignity of the human being.

The possibility of choice appears to be related to two elements: the consequences of the choices made, and the limits on the freedom of the other person.

We have beliefs and values imposed upon us that limit us. If we can choose what to believe, we can confront new situations that arise. It makes us feel free in any case (E138).

Parallel to freedom is love, in the widest of senses, as a value that gives meaning to life.

Paolo Freire (1978) related these two concepts. The human being is a creature of relations, not merely one of contacts. The human being is with the world, and not merely in it.

The act of providing care is a relation that makes the expression of love possible, as an objective, and of freedom, as a means to achieve it. Opening to the reality of suffering in which we may find a multiplicity of positions is the expression of different ways of adapting to situations, in which there is the possibility of choosing aid in order to feel free, and therefore dignified.

The relation of these values underlies the principle of autonomy understood as freedom of choice and as choice based on the recognition and assumption of certain self-chosen moral values (Torralba, 1999). The autonomy of the patient makes it possible to freely choose how to adapt to the reality of suffering. 


\subsection{Empathy in the Face of Extreme Suffering}

The third category to emerge is empathy in the face of extreme suffering.

Students perceived that empathy has limits imposed by two elements: withholding empathy to guard against the possible suffering of the other person:

The insensitivity and lack of empathy arising in most people were the consequence of all the years that they had spent there (E002).

What pains me most is the insensitivity of others towards us, we cause fear when we speak of what happened to us (E098).

And lack of knowledge concerning the experience of a level of suffering that is so high that only one who has already undergone it can comprehend it.

...there are several types/degrees of empathy: that which keeps you from fulfilling your needs and blocks you, and that which helps you maintain a healthy distance (E085).

It is impossible to empathize in certain situations (E105).

No one can stand talking about a topic or an experience that has marked one's life so greatly $[\ldots]$ you can only understand this if you have lived or are living it. It cannot be explained in words (E042).

Empathy bears a statistically positive relation to prosocial behavior (Batson, Batson, Slingsby et al., 1991; Hoffman, 1987; Bandura, Barbaranelli, Caprara \& Pastorelli, 1996). Relating to the suffering of others encourages altruistic acts and reduces personal aggression (Hoffman, 1987).

Empathy is one of the most important attitudes in nursing, as it improves contact with others, not only in terms of the technical quality of the activity, but also the ontological (Watson, 2002) which is reinforced, nourished, and rounded out in the encounter with another being.

\subsection{Meaning of Suffering}

The meaning of suffering emerged as a category among the students. This category has two opposing sides: despair, spiritual suffering:

...losing hope and value, your thinking is deeply affected, and this is reflected physically: your resistance to disease is lowered (E094).

When, in the face of a hard situation, when everything is taken from you-your past life, your loved ones, your clothing and possessions-the only thing that remains is your dignity, your honor, and your values. When they try to take these as well, you feely empty and dehumanized. Nothing of you is left in your body. This has to be one of the worst crises that a person can experience (E060).

It is hard to think about a situation that is so different, when they take the clothes you are wearing and you are left naked in front of others, some in the same situation as you, and some with threatening eyes (E097). They take away your personal belongings - the things that connect you with your identity. And you are lost (E105).

Thinking about the capacity of the human being to find appropriate mechan- 
isms for enduring total suffering, when in a situation of absolute despair, simply finding strength in the image of a loved one. It is moving how the intensity of past experience can help shut out the horrifying present situation in which one may find oneself $(E 105)$.

And suicide on the one hand, and strength and confrontation on the other:

Hope plays an important role in people and in their way of viewing their lives. That's why many people with beliefs and values, and those who are religious, are stronger when it comes to withstanding a life with suffering [...] while others commit suicide because they do not see an end to suffering without ending their lives (E097).

Suicide may be because one no longer wants to live, but it may also be a way out of a situation (E076). The person who has an objective, a goal, an end, can withstand suffering (E097).

A great truth is that we are born alone and die alone. What we suffer, we suffer alone, and we have the choice to suffer with dignity (E015).

... suffering makes you strong. You discover the positive in suffering because you find strength and knowledge of what you are capable of (E121).

Numerous authors have related the meaning of life with the search for meaning in suffering, illness, and death (Frankl, 1988; Davis, Nolen-Hoeksema, \& Larson, 1998).

There are times when resistance in the face of painful and difficult situations pushes our being to the very limit, where we have feelings and thoughts about our existence (Amar, 2001).

\subsection{Meaning of Life}

The students constructed the category of the meaning of life with: Struggling for the values that one believes in, hope (struggle, survival), freedom of thought,

Despite all the suffering, the pain, and everything taken away, there was still freedom, remaining inside. And that provided the strength to go on living (E062).

Hope plays an important role in people and in their way of viewing their lives. That's why many people with beliefs and values, and those who are religious, are stronger when it comes to withstanding a life with suffering [...] while others commit suicide because they do not see an end to suffering without ending their lives (E097).

Without freedom there is no hope or desire to go on living, which is why it is the last thing to vanish from our thinking [...] the spirituality of each individual is defined by freedom ( $E 067$ ).

Virginia Henderson lays out in her model of care the importance of fulfilling the 14 needs of the human being, in order to recover the state of health. My final reflection, by way of conclusion, is that robbing one of the fundamental rights of humans, freedom, not only causes the loss of each of the needs and resulting damage to a person held in a concentration camp, or in a hospital. It also establishes a before and after for the meaning of existence (E088). 
Existing is more than living because it is more than being in the world. It is being in it and with it. For this reason meaning requires self-transcendence (Frankl, 1988; Yalom 1984). The development of the spiritual dimension enables the communicative union of one who exists with the objective world, and gives to existence the sense of the critical which is lacking in simply living. Transcending, discerning, communicating, and participating are the exclusive province of existing (Delgado, 2007). Existing is individual, but it is only realized in relation to others, and in communication with them. For more on this see Jaspers' Origin and Goal of History and Reason and Existenz.

\section{Conclusion}

The reflections of future healthcare professionals represent a contribution to comprehending meaning in human life-a primordial necessity that is ever present in situations of extreme adversity, such as illness, suffering and death.

This reflection is part of the process of creating professionals competent in total care, in that it leads to increased sensitivity and humanization of care, and indeed of existence.

First year students in a university degree program in nursing understand meaning as it relates to life and suffering. There is no life without meaning, nor is there meaning that is not part of life, such as that of suffering in the face of adversity. The meaning of life is related to freedom and love. Each human being is capable of stepping outside himself or herself and reaching out to others so that they may jointly discover the reasons that make life worth living. Furthermore, the search for meaning is related to the freedom to choose what meaning to apply to each event and the freedom to decide how to live it. In order to confront the search for meaning in situations marked by suffering, the individual may manifest various attitudes that are seen primarily as defense mechanisms, but in which inhere values such as hope and resilience. Understanding the process of the search for meaning enables the healthcare professional to empathize with the person being cared for. Nevertheless, the students felt that empathy is limited in extreme cases by the absence of elements of connection with the situation of the other person. For Víctor Frankl, there are three paths that lead to exploring the meaning of life, and these may be of help to the students in their reflections: that which you create yourself, and what you do; loving another person, and having someone to give yourself to; and finding an explanation for the "why", even in situations of total despair. The three paths are of use to us in finding meaning in nursing: feeling useful in providing personal care; loving another human, especially one in need; and finding the value in life, in particular when suffering is unavoidable.

\section{Ethical Approval}

All procedures performed in studies involving human participants were in accordance with the ethical standards of the institutional and/or national research 
committee and with the 1964 Helsinki declaration and its later amendments or comparable ethical standards.

\section{Informed Consent}

Informed consent was obtained from all individual participants included in the study.

\section{Acknowledgements}

Funding for this project was provided by the Campus Docent Sant Joan de Déu.

\section{References}

Acklin, M., Brown, E., \& Mauger, P. (1988). The Role of Religious Values in Coping with Cancer. Journal of Religion and Health, 22, 322-333. https://doi.org/10.1007/BF02279928

Amar, J. J. (2001). Reflexión sobre el sufrimiento a partir del pensamiento de Karl Jaspers. Psicología desde el Caribe, 7, 70-84.

Angermeyer, M. C., \& Killian, R. (2000). Modelos teóricos de Calidad de Vida en trastornos mentales. In H. Katschnig, H. Freeman, \& N. Sartorious (Eds.), Calidad de vida en los trastornos mentales (pp. 19-29). Barcelona, España: Masson.

Antonovsky, A. (1987). The Jossey-Bass Social and Behavioral Science Series and the Jossey-Bass Health Series. Unraveling the Mystery of Health: How People Manage Stress and Stay Well. San Francisco, CA: Jossey-Bass.

Bandura, A., Barbaranelli, C., Caprara, G., \& Pastorelli, C. (1996). Multifaceted Impact of Self-Efficacy Beliefs on Academic Functioning. Child Development, 67, 1206-1222. https://doi.org/10.2307/1131888

Barbera, E., Garcia, I., \& Fuertes-Alpiste, M. (2017). A Co-Design Process Microanalysis: Stages and Facilitators of an Inquiry-Based and Technology-Enhanced Learning Scenario. The International Review of Research in Open and Distributed Learning, 18, No. 6. https://doi.org/10.19173/irrodl.v18i6.2805

Batson, C. D., Batson, J. G., Slingsby, J. K., Harrell, K. L., Peekna, H. M., \& Todd, R. M. (1991). Empathic Joy and the Empathy-Altruism Hypothesis. Journal of Personality and Social Psychology, 61, 413-426. https://doi.org/10.1037/0022-3514.61.3.413

Berger, P. L., \& Luckmann, T. (1968). La construcción social de la realidad. Madrid: H.F. Martínez de Murguía.

Bonilla, F. S., \& Rapso, M. (1997). Sentido de la vida en personas mayores de 50 años. Revista Reflexiones, 59, No. 1.

Cabrera, M., Lluch, A., \& Casas, I. (2008). Reflexiones sobre dolor no físico y sufrimiento desde la perspectiva de enfermería. Revista Cubana de Enfermería, 24.

Carper, B. (1978). Fundamental Patterns of Knowing in Nursing. Advances in Nursing Science, 1, 13-23. https://doi.org/10.1097/00012272-197810000-00004

Cassaretto, M., \& Martínez, P. (2012). Razones para vivir en jóvenes adultos: Validación del RFL-YA. Revista de Psicología (PUCP), 30, 169-188.

Casullo, M. (2005). Ideaciones y comportamientos suicidas en adolescentes: una ugencia social. Anuario de Investigaciones, 12, 173-182.

http://www.redalyc.org/pdf/3691/369139941017.pdf

Davis, C. G., Nolen-Hoeksema, S., \& Larson, J. (1998). Making Sense of Loss and Bene- 
fiting from the Experience: Two Construals of Meaning. Journal of Personality and Social Psychology, 75, 561-574. https://doi.org/10.1037/0022-3514.75.2.561

De Llanos, P. (2001). Pensamiento antropológico de Laín Entralgo (Tesis doctoral). Sevilla: Universidad de Sevilla.

Delgado, C. (2007). Sense of Coherence, Spirituality, Stress and Quality of Life in Chronic Illness. Journal of Nursing Scholarship, 39, 229-234. https://doi.org/10.1111/j.1547-5069.2007.00173.x

Fiorentino, M. T. (2008). La construcción de la resiliencia en el mejoramiento de la calidad de vida y la salud. Suma Psicológica, 15, 95-114.

Frankl, V. (2000). En el principio era el sentido: Reflexiones en torno al ser humano. Madrid: Paidós.

Frankl, V. E. (1988). El hombre en busca de sentido. Barcelona: Herder.

García-Alandete, J., Gallego-Pérez, J. F., \& Pérez-Delgado, E. (2009). Sentido de la vida y desesperanza: Un estudio empírico. Universitas Psychologica, 8, 447-454.

García-Monge, J. A. (2010). La Esperanza en la Experiencia de Sufrimiento Humano. El Psicólogo Humanista y su Ayuda en la integración del dolor. Clínica Contemporánea, 1, 19-29. http://psicologoslaureanocuesta.org/articulos/PsicologoHumanista.pdf https://doi.org/10.5093/cc2010v1n1a3

Glaser, B. G., \& Strauss, A. L. (2017). Discovery of Grounded Theory. Strategies for Qualitative Research. New York, NY: Routledge.

Gray, B. (2009). The Emotional Labour of Nursing-Defining and Managing Emotions in Nursing Work. Nurse Education Today, 29, 168-175.

https://doi.org/10.1016/j.nedt.2008.08.003

Guba, E., \& Lincoln, Y. (1989). Fourth Generation Evaluation. London: Sage Publications.

Hernández-Sampieri, R., Fernández-Collado, C., \& Baptista-Lucio, M. P. (1998). Metodología de la investigación. México: McGraw-Hill.

Hoffman, M. L. (1987). The Contribution of Empathy to Justice and Moral Judgment. In N. Eisenberg, \& J. Strayer (Eds.), Cambridge Studies in Social and Emotional Development. Empathy and Its Development (pp. 47-80). New York, NY: Cambridge University Press.

Hold, J. L., Blake, B. J., \& Ward, E. N. (2015). Perceptions and Experiences of Nursing Students Enrolled in a Palliative and End-of-Life Nursing Elective: A Qualitative Study. Nurse Education Today, 35, 777-781. https://doi.org/10.1016/j.nedt.2015.02.011

Janoff-Bulman, R. (1992). Shattered Assumptions: Towards a New Psychology of Trauma. New York: Free Press.

Jaramillo, A. L., Carvajal, S. M., Marín, N. M., \& Ramírez, A. M. (2008). Los estudiantes Universitarios Javerianos y su respuesta al sentido de la vida. Pensamiento psicológico, 11, 199-208.

Kérouac, S., Pepin, J., Ducharme, F., Duquette, A., \& Major, F. (2001). El Pensamiento Enfermero. Barcelona: Masson.

Koven, M. J. (2001). Blaxploitation Cinema. Pocket Essentials.

Längle, A. (2005). La Búsqueda de Sostén. Análisis Existencial de la Angustia. Terapia Psicológica (Chile), 23, 57-64.

Laverde, M. (1998). Espiritualidad y afecto en el cuidado de enfermería. Bogotá: Universidad Nacional de Colombia.

Lima, A. B., \& Rosa, D. (2008). O sentido de vida do familiar do paciente crítico. Revista da Escola de Enfermagem da USP, 42, 547-553. 
https://doi.org/10.1590/S0080-62342008000300019

Lipowski, Z. J. (1970). Physical Illness, the Individual and the Coping Processes. Psychiatry in Medicine, 1, 91-102. https://doi.org/10.2190/19Q3-9QL8-XYV1-8XC2

McSherry, W., \& Cash, K. (2004). The Language of Spirituality: An Emerging Taxonomy. International Journal of Nursing Studies, 41, 151-161. https://doi.org/10.1016/S0020-7489(03)00114-7

Pearson, P. R., \& Sheffield, B. F. (1974). Purpose-in-Life and the Eysenck Personality Inventory. Journal of Clinic Psychology, 30, 562-564.

Peña, C. A., \& Carlos, A. (2012). El proyecto de vida y la enfermería. Tendencia antropológica, histórica, filosófica, epistémica.

http://www.portalesmedicos.com/publicaciones/articles/4831/1/El-proyecto-de-vida-yla-Enfermeria-Tendencia-antropologica-historica-filosofica-epistemica.html

Pessini, L., \& Bertachini, L. (2006). Nuevas perspectivas en cuidados paliativos. Acta Bioethica, 12, 231-242. https://doi.org/10.4067/S1726-569X2006000200012

Ramírez-Osorio, P., \& Hernández-Mendoza, E. (2012). Resiliencia familiar, depresión y ansiedad en adolescentes en situación de pobreza. Revista de Enfermería del Instituto Mexicano del Seguro Social, 20, 63-70.

Rice, F. P. (1997). Desarrollo humano. Barcelona: Pearson Educación.

Schwartzmann, L. (2003). Calidad de vida relacionada con la salud: Aspectos conceptuales. Ciencia y enfermería, 9, 9-21. https://doi.org/10.4067/S0717-95532003000200002

Shiratori, K., Figueiredo, N. M., \& Teixeira, M. S. (2006). El sentido de ser humano: Una base para reflexionar sobre el cuidado de enfermería. Enfermería Global, 5, No. 1.

Strauss, A., \& Corbin, J. M. (1997). Grounded Theory in Practice. London: Sage.

Torralba, F. (1999). Los límites del principio de autonomía. Consideraciones filosóficas y bioéticas. Labor Hospitalaria, 251, 13-31.

Vickberg, S. M., Bovbjerg, D. H., DuHamel, K. N., Currie, V., \& Redd, W. H. (2000). Intrusive Thoughts and Psychological Distress among Breast Cancer Survivors: Global Meaning as a Possible Protective Factor. Behavioral Medicine, 25, 152-160. https://doi.org/10.1080/08964280009595744

Viera, A., López, S., \& Barrenechea, A. (2006). El bienestar psicológico, un indicador positivo de la salud mental. Revista cubana de salud y trabajo, 7, 34-39.

Vinaccia, S., \& Quiceno, J. (2012). Calidad de vidarelacionada con la salud y enfermedadcrónica: estudioscolombianos. Psychologia, 6, 123-136.

Watson, J. (2002). Nursing: Seeking Its Source and Survival. ICUs and Nursing Web Journal, 1-7. https://www.watsoncaringscience.org/files/PDF/WatsonICU02.pdf

Yalom, I. D. (1984). Psicoterapia Existencial. Barcelona: Herder.

Zika, S., \& Chamberlain, K. (1992). On the Relation between Meaning in Life and Psychological Well-Being. British Journal of Psychology, 83, 133-145.

https://doi.org/10.1111/j.2044-8295.1992.tb02429.x 